\title{
Privatisation and Employees' Job Security: Lessons From Bangladesh
}

\author{
Mehadi Mamun \\ Victorian Institute of Technology, Australia
}

\begin{abstract}
Received: Apr. 16, 2021 Accepted: May 18, 2021 Online published: Jun. 2, 2021
doi:10.5296/ijhrs.v11i2.18533ＵRL: https://doi.org/10.5296/ijhrs.v11i2.18533
\end{abstract}

\begin{abstract}
This study looks at the human face of privatisation and examines employees' job security in privatised state-owned enterprises in Bangladesh. The study uses semi-structured face-to-face interviews and document analysis of relevant secondary source materials. The study finds that permanent employees at the state-owned organisations feel secure in their jobs. By contrast, an average of $67 \%$ of permanent employees at the privatised state-owned organisations feel insecure about their jobs. The findings have important implications for the privatisation programmes and suggests that there is a need to place greater emphasis on a more context sensitive approach to privatisation programmes in Bangladesh.
\end{abstract}

Keywords: privatisation, job security, employees, Bangladesh.

\section{Introduction}

Foreign aid has played an important role in the economic development of many countries across the world through different periods of history (Banerjee, 2006). In more recent times, a significant proportion of foreign aid has become what is commonly referred to as 'conditional'. Conditional aid is aid provided by international institutional donors to the governments of developing countries with the requirement that they implement certain prescribed policies. These institutions, such as the World Bank and the IMF, require certain conditions in the belief that the adoption of particular policies will assist in ensuring that the aid is used in ways that are more likely to decrease poverty and more broadly improve the economic, social and political situation in the area to which the aid is targeted (Lastra, 2002; Stern et al., 2005).

In general, these prescribed policies are inspired by neo-classical interpretations of economic development and focus on private sector-led growth through which, it is thought, a more liberalised market is able to address some of the more tangible structural impediments to healthy economic growth in recipient countries (Ensign, 2001). A common condition tied to foreign aid is that recipients privatise parts of their economy. The IMF and the World Bank, 
in particular, have pursued privatisation policies when providing aid to Less Developed Countries (LDCs) (Cook, 1986; Adam et al., 1992; Craig, 2000). As a consequence, various governments of LDCs, including Bangladesh, have adopted privatisation programmes at the demand of international institutional donors (Craig, 2000). For instance, the World Bank granted US\$ 388.39 million between 2004 and 2010 to Bangladesh on the condition that the Bangladeshi government privatised and restructured its state-owned organisations (World Bank, 2011b). It is now widely recognised that privatisation is central to World Bank and IMF aid policy in Bangladesh.

Unlike most research on privatisation, this study has gone beyond evaluating aid agency-directed privatisation in terms of its impact on profitability and other quantifiable measures of financial performance, and looked closely at the impact of privatisation on employees in Bangladesh. The present study, hence, seeks to explore the following research question: What is the impact of privatisation in terms of its effects on employees' job security in Bangladesh? This study presents the answers and findings from five in-depth case studies on fully operational privatised state-owned Bangladeshi businesses in the manufacturing industry that have been privatised by the Privatisation Commission and compares these cases with five state-owned businesses that are comparable in terms of industry and size. This study aims at contributing to the body of research by presenting a deeper understanding of the impact of privatisation on Bangladeshi employees' job security, which may provide useful insights into the privatisation programmes in Bangladesh.

\section{Privatisation and Job Security in Bangladesh: A Literature Review}

Foreign aid is an important element of development paradigm and a major tool to reduce poverty (Bird, 2004). Some now industrially advanced and prosperous countries are among the beneficiaries of foreign aid. For instance, the United States, now the world's leading aid donor, was assisted by the United Kingdom in the middle of the 19th century. In the 20th century, many western European countries, including the UK, benefited substantially from The Marshall Plan, under which some US\$13 billion in aid flowed from the USA to European countries after the Second World War (Rist, 2002; Banerjee, 2006). In the late 1990s, the IMF distributed some US\$117 billion to Asian countries ( $\$ 57$ billion to South Korea, $\$ 43$ billion to Indonesia, and $\$ 17$ billion to Thailand) during the Asian Financial Crisis (Felix, 1998). It is calculated that more than US\$100 billion in foreign aid is distributed every year globally (World Bank, 2012).

The World Bank and the IMF, which are the key providers of multilateral aid, have used conditionality since their inception in 1944 and 1945 respectively (Malmqvist, 2000). Up to the early 1980s, conditionality largely focused on macroeconomic policies, such as monetary policy (Morrissey, 2004). The IMF and World Bank introduced Structural Adjustment Programmes (SAPs) through conditionality for developing countries in the 1980s. These SAPs included internal changes (particularly deregulation and privatisation) as well as external changes, mainly the shrinking of trade barriers (Ensign, 2001). Cook (1986) defines privatisation as the purposeful sale of state-owned enterprises by a government to private proprietors. Privatisation is thought to increase investment and efficiency, and decrease 
government expenditure (Adam et al., 1992; Flemming \& Mayer, 1997). Under privatisation policy, state-owned organisations are required to be sold regardless of their relative profitability (Goodman \& Loveman, 1991). Major institutional donors have embraced privatisation as the cornerstone of their aid and development policies in developing countries (Chowdhury, 1990; Uddin \& Hopper, 2001; Boubakri et al., 2008).

Over the past three decades, international aid agency-directed privatisation has been the topic of widespread research. Among this research, two distinct perspectives have come to dominate what has become a heated debate. The first is posed primarily by neo-classical and free-market economists and the research arms of international development agencies such as the IMF and the World Bank. Reports from these agencies contend that privatisation is central to any long-term process of economic reform (World Bank, 1995; Brune et al., 2004; Boubakri et al., 2004). Opposing this interpretation, some aid watchers and economists (Potts, 1995; Karatas, 1995; Khan, 2000; Letza \& Smallman, 2001; Dijkstra, 2002; ActionAid, 2004) argue that external aid agency-driven privatisation has little, if any, visible positive impact on the social and economic development of recipient countries.

As outlined above, major international aid donors see privatisation as a way to increase efficiency and decrease government expenditure in developing countries (Adam et al., 1992; World Bank, 1995; Flemming \& Mayer, 1997; Brune et al., 2004). According to this perspective, state-owned enterprises (SOEs) are unable to boost performance and productivity because of underpaid and insufficiently monitored managers, political intervention, and influential labour unions. Boubakri et al. (2004) conducted studies on privatised enterprises in 10 developing countries and concluded that privatisation brings major improvements to efficiency, output, and profitability. Likewise, Loc et al., (2006) examined the performance of 121 former state-owned enterprises in Vietnam and found major improvements in sales revenues, profitability, and employee income in those privatised enterprises.

However, authors such as Potts (1995) and Dijkstra (2002) argue that privatisation results in the transfer of domestically owned resources to foreign companies or national politically-aligned influential groups, and in so doing the aim of public prosperities are replaced by the aim of private accumulation. There are several empirical studies arguing that state-owned enterprises are not necessarily less efficient than those in private ownerships. Karatas (1995) compared pre- and post-privatisation company performance among Turkish firms based on financial measures such as productivity, turnover, and profit margins. He found no relationship between privatisation and the firm's financial performance. A report on developing countries prepared by the IMF's Independent Evaluation Office (IEO) (2002) showed that prescriptive donor policies had failed to bring financial steadiness to developing countries. In addition, Gupta et al. (1999) and Stiglitz (2003) argued that IMF policies failed to address the lack of safety nets to help employees who might lose their jobs following privatisation, which in turn exacerbated political and social instability.

In the case of Bangladesh, as a developing country, it has relied on foreign aid as its major source of external finance since its independence in 1971. According to the Ministry of 
Finance of Bangladesh (2003, 2012) and Khatun (2018), from 1971 to 2016 over US\$69 billion in foreign aid has been provided to Bangladesh. Much of this aid has come from major international institutional donors such as the World Bank and the International Monetary Fund (IMF) and has been provided on the condition that the government commits to several reforms. One condition has been that the Bangladeshi government privatises its state-owned enterprises. For Example, the IMF granted about US\$ 954.4 million between 1990 and 2007 to Bangladesh under the Poverty Reduction and Growth Facility (PRGF) arrangement, and the key condition of that arrangement included privatisation or closure of state-owned enterprises (SOEs) (IMF, 2011). The World Bank jointly with three other development partners, such as the Asian Development Bank, the Government of Japan, and the United Kingdom's Department for International Development also prepare a Country Assistance Strategy (CAS) for Bangladesh. One of the strategic priorities of CASs (2001, 2006, 2011a) was to create an enabling environment for private sector-led economic growth and privatisation of state-owned enterprises (SOEs). Hence, following aid agencies' advice to privatise SOEs efficiently, the Bangladesh government formed the Privatisation Board in 1993 and privatised 39 state-owned enterprises (Uddin \& Hopper, 2001; Chowdhury, 2008; Privatisation Commission, 2010a, 2010b). The Bangladesh government also formed the Privatisation Commission in July 2000 with more financial and administrative power to well run the privatisation programme through the enactment of the Privatisation Act 2000 and dissolved the Privatisation Board after the Privatisation Commission's establishment. The Privatisation Commission privatised 38 state-owned enterprises between its establishment and 2015 (Privatisation Commission, 2010b, 2015). The Bangladesh government merged the Privatisation Commission and Board of Investment into the Bangladesh Investment Development Authority in 2015 to boost investment and industrialisation in the country.

A comprehensive study of the privatisation of state-owned enterprises (SOEs) in Bangladesh is relatively limited. Most research on privatisation in Bangladesh has been involved with measuring its impact on profitability and performance. The World Bank's country assistance strategy $(2006,2011 \mathrm{a})$ pointed out that privatisation in Bangladesh would increase business efficiency, promote investment and economic growth. Boubakri et al. (2008) conducted a study on the privatised enterprises in Bangladesh and found that privatisation carried out boosts to profitability and output. However, opponents argued that state-owned enterprises in Bangladesh followed many development goals in which profit maximisation was ranked below than the provision of jobs (Sobhan, 2002; Momen, 2007). Besides, Sen's (1997) study found that only $39.4 \%$ of the Bangladeshi privatised enterprises were profitable and $53.9 \%$ were making a loss. Likewise, Ahmed (2004) did not find any clear relationship between privatisation and improved financial performance in Bangladesh. Islam (2015), hence, saw the peril of privatisation programmes in Bangladesh that led many businesses to the edge of collapse after privatisation.

As the above discussion reveals that most research on privatisation has been involved with measuring its impact on profitability and performance, there is space to expand our insights of the impact of privatisation on employees, directly through evaluating the impact on employees' job security. Job security refers to an employee's perception about his/her job or 
the important feature of the job, is secure (Burchell, 2014). Hence, this study focuses on employees and provides insights into the impact of privatisation on workers' job security in Bangladesh.

\section{Methodology and Data Collection}

The study has employed five case studies as the multiple cases within the same study increase the possibility of finding similar outcomes and the development of similar findings over multiple cases inform to robust findings (Yin, 2003; Noor, 2008). The study has also used semi-structured face-to-face interviews with permanent employees and casual employees from the five case study organisations and document analysis of relevant secondary source materials including company documents relating to redundancy rates, permanent and casual workers numbers. An indirectly structured interview allows themes to emerge as participants make their own meanings from the situations (McMurray et al., 2004), and multiple sources of data improve the study's validity and reliability (Parry, 1998). Thus, the study has measured job security through employee's own perception which is referred to as subjective job security, and objective job security through redundancy rates and permanent vs casual employees' rates (Burchell, 2014).

As mentioned earlier, a total of 38 state-owned enterprises were privatised by the Privatisation Commission between its establishment in 2000 and its amalgamation into the Bangladesh Investment Development Authority in 2015. Of the 38 privatised organisations, 20 were closed, 14 were fully operational, three had changed businesses, and one was partly operational. This study has focused on the 14 fully operational organisations. Of the 14 organisations, four were from the chemical industry, three were from the food industry, two were from the textile industry, two were from the steel industry, one was from the forest industry, one was from the fisheries industry, and one was from the jute industry. Thus, 14 organisations were belonged to the seven industries. Of the seven industries, the five case study organisations were from the five industries. The five case study organisations (sugar mill, textile mill, jute mill, paper mill, and fishing net factory) were of varying size, span different industries, and based in different geographical districts of Bangladesh. This assortment offered the scope for comparing the impact of privatisation on employees across different industries and size. In addition, employees' job security at the five privatised case study organisations were compared with the employees' job security at five state-owned organisations that were belonged to the same industries and size, which also offered to explore the impact of privatisation on employees' job security in privatised organisations.

The fieldwork involved data collection from the five privatised and five state-owned organisations through semi-structured face-to-face interviews from 2015 to 2016. In total 100 interviews were conducted across the five privatised organisations (20 interviews from each organisation), and the same number of interviews were conducted in five state-owned organisations. Interviewees from each organisation were selected through proportional stratified random sampling from a list of staff to avoid sampling errors and predisposition. Employees of an organisation were first divided into two segments such as permanent employees (male and female) and casual employees (male and female). After dividing 
employees into two segments, proportional stratified random sampling was conducted to obtain potential interviewees' names. For example, all male permanent employees' names were entered into a computer program to obtain potential interviewees' names randomly from the male permanent employees, and it was ensured that the proportion of this category in the whole sample was the same as the proportion in the staff list. This method facilitated an in-depth understanding of all kinds of employees' views.

Access to the organisations was sought through direct contact with the appropriate authorities and relevant documents were collected from the five privatised and five state-owned organisations. Most of the policy documents, annual reports, documents detailing the Bangladesh government's rules and regulations, and other relevant literature used in this study were available in the public domain. Staff list from each organisation was also collected after obtaining written consent from the authority to participate in this study. All interviews were conducted outside of the workplace and after office hours, wherever interviewees felt safe. This approach was taken to disguise the identity of the interviewees from owners to protect them from any repercussions of participating in this study. In addition, no identifiable information of the interviewees was obtained to provide maximum protection of their anonymity. For the same purpose, oral instead of written consent was sought from the interviewees. The interviews were conducted in Bengali and an audio recording was made with the participants' permission.

\section{Data Analysis and Major Findings}

All audio recorded semi-structured interviews were transcribed and then translated from Bengali into English, and the interviews were transcribed and translated as true and as faithful to the participant's words as possible. Silverman (2005) argued that transcribed data generally provides a very good indication of what participants usually do. All transcribed data of this study was read several times and it captured sufficient detail of what the participants conveyed in their interviews.

The five privatised and five state-owned organisations' policy documents relating to redundancy rates, permanent vs casual employees' rates, and other relevant documents were analysed to know how the employees' job securities were preserved. The analytic procedure entailed finding, selecting, and synthesising data contained in documents. Rapley (2007) stated that documents are examined and interpreted to extract meaning, gain sense, and develop knowledge of a phenomenon.

After analysing the documents and interviews, it was found that the redundancy rate in the privatised jute mill was $25 \%$ as it recruited new employees after privatisation, and the mill employed $71 \%$ permanent employees and $29 \%$ casual employees. On the other hand, state-owned jute mill employed $74 \%$ permanent employees and $26 \%$ casual employees. There was major differentiation, however, in terms of perception of job security. All the interviewees who were permanent employees at the state-owned jute mill said that they had job security, though about $67 \%$ of the permanent employees from the privatised jute mill said that they did not have job security as the jobs were in the managements' hands. Most of the privatised jute mill's casual employees were dissatisfied, citing the inability to get permanent 
positions after long periods working on a casual basis than their counterparts at the state-owned jute mill.

The privatised sugar mill employed about $67 \%$ permanent employees and 33\% casual employees, and its redundancy rate was $34 \%$. On the other hand, in the state-owned sugar mill, $79 \%$ of the employees were permanent and $21 \%$ were casual. At the state-owned sugar mill, all the permanent employees felt secure in their jobs. This was different from the privatised sugar mills. About $71 \%$ of the privatised sugar mill's permanent employees said that their jobs were not secure and were at the mercy of management. Similarly, most casual employees at the privatised sugar mill than the state-owned sugar mill were dissatisfied and felt insecure. One of the casual machine operators from the privatised mill said: ' $I$ am working here for more than four years, but still waiting to be permanent.'

In the privatised textile mill, about $62 \%$ of the employees were permanent and $38 \%$ were casual, and its redundancy rate was $37 \%$. On the other hand, the state-owned textile mill employed $47 \%$ permanent employees and 53\% casual employees. In terms of job security, all the permanent employees from the state-owned textile mill felt their positions were secure. By comparison, most permanent employees (77\%) and all casual employees at the privatised textile mill felt insecure.

About $72 \%$ of the privatised paper mill's workforce were permanent employees and $28 \%$ were casual, and its redundancy rate was $20 \%$. At the state-owned paper mill, about $71 \%$ of its employees were permanent and $29 \%$ were casual. Permanent employees at the state-owned paper mill regarded their jobs as secure. By contrast, about $60 \%$ of the permanent employees from the privatised mill said that their jobs were not secure, and their future was in the hands of management. Similarly, most of the privatised mill's casual employees were not happy, citing frustration at the delay in securing permanent positions than their counterparts at the state-owned mill.

In the privatised fishing net factory, about $62 \%$ of the employees were permanent and $38 \%$ were casual, and its redundancy rate was $35 \%$. The state-owned factory employed about $64 \%$ permanent employees and $36 \%$ casual employees. At the state-owned factory, all the permanent employees felt secure in their jobs. By contrast, about $62 \%$ of the permanent employees at the privatised fishing net factory felt insecure in their jobs. All the casual employees at the privatised factory and $30 \%$ of the casual employees at the state-owned factory were dissatisfied, citing delays in shifting from casual to permanent positions.

\section{Cross-Case Findings and Conclusions}

After the analysis of each case study, the individual findings have been combined and brought together the five case studies to provide a more integrated picture. Yin (2003) refers cross-case analysis as a technique that is particularly useful in the analysis of multiple case studies, which is generally easier to follow and more robust. Thus, the cross-case analysis summarises the discussion of the five case studies in order to draw overall conclusions from the study.

The study has found that permanent employees at the state-owned factories feel secure in 
their jobs. By contrast, an average of $67 \%$ of permanent employees at the five privatised case study organisations feel insecure about their jobs. The study has also found that in the five privatised organisations, the redundancy rates are on average $30 \%$ after privatisation. In addition, most of the privatised factories have employed more casuals than the state-owned factories. Across the privatised case study organisations, more casual employees have reported having less chance of getting ahead professionally and felt insecure about their jobs than their counterparts at the state-owned organisations as employees have the right to be a member of a trade union at state-owned organisations. In general, however, casual workers' vulnerability and poor employment opportunities elsewhere compel them to continue their jobs.

The study has also found that organisational size and industry type of the privatised organisations have not affected employees' job security. Common findings and patterns from the case study organisations' interviews and documents suggest that the findings of this study can be generalised and applied across other privatised organisations workers' job security. The findings have important implications for the privatisation programmes in Bangladesh as they raise issues associated with the uncritical application of privatisation programmes. This study suggests that there is a need to place a context-sensitive approach to privatisation policies in Bangladesh. Bangladeshi policymakers should be highly cautious when selecting state-owned enterprises for privatisation as most of the privatised organisations are closed down. Indeed, a technical committee should be formed to identify appropriate state-owned enterprises for privatisation and give advice on procedures to protect workers' interests and rights.

Hitherto, most research on privatisation in Bangladesh has examined the relationships between privatisation and profitability, and little scholarly attention has been given to find out the impact of privatisation on employees. As the privatisation scheme has become a key instrument of international institutional aid donors, and its consequences affect millions across the developing world, the need to unveil the human face of privatisation policies has never been more crucial. This study, therefore, looks at the human face of privatisation and tests employees' job security in privatised organisations in Bangladesh. However, this research is exploratory in nature, and it concentrates mainly on the 'what' but not the 'why'. As with most research, this study cannot stand alone and further research is suggested. The findings of this research are based on case studies of five privatised organisations in Bangladesh. There is potential for further research by using a different sample. In particular, an avenue of further research can be to compare the findings of this study with the experiences of employees in privatised organisations in other developing countries.

\section{References}

ActionAid. (2004). Money Talks: How Aid Conditions Continues to Drive Utility Privatization in Poor Countries. UK: Action Aid International.

Adam, C., Cavendish, W., \& Mistry, P. S. (1992). Adjusting Privatization-Case Studies from Developing Countries. London: Currey. 


\section{Macrothink}

International Journal of Human Resource Studies ISSN 2162-3058 2021, Vol. 11, No. 2

Ahmed, M. U. (2004). Privatization in Bangladesh. Geneva: International Labour Organization.

Banerjee, A. V. (2006). Making Aid Work. USA: The MIT Press.

Bertaux, D. (1981). From the life-history approach to the transformation of sociological practice. In D. Bertaux (Ed.), Biography and society: The life history approach in the social sciences (pp. 29-45). London: Sage Publications.

Bird, G. (2004). Growth, poverty and the IMF. Journal of International Development, 16(4), 621-637. https://doi.org/10.1002/jid.1111

Boubakri, N., Cosset, J. C., \& Guedhami, O. (2004). Privatization, corporate governance and economic environment: Firm-level evidence from Asia. Pacific-Basin Finance Journal, 12(1), 65-90. https://doi.org/10.1016/S0927-538X(03)00016-7

Boubakri, N., Cosset, J. C., \& Guedhami, O. (2008). Privatisation in Developing Countries: Performance and Ownership Effects. Development Policy Review, 26(3), 275-308. https://doi.org/10.1111/j.1467-7679.2008.00411.x

Burchell, B. (2014). Job Security. In A.C. Michalos (Ed.), Encyclopaedia of Quality of Life and Well-Being Research. Dordrecht: Springer. https://doi.org/10.1007/978-94-007-0753-5_1569

Brune, N., Garrett, G., \& Kogut, B. (2004). The International Monetary Fund and the Global Spread of Privatization. IMF Staff Papers, 51(2). Washington DC: International Monetary Fund.

Chowdhury, J. A. (1990). Privatization in Bangladesh. Working Paper Series no. 92. The Hague: The Institute of Social Studies.

Chowdhury, M. A. S. (2008). An Overview on Privatization Program. Bangladesh: Privatization Commission.

Cook, P. (1986). Liberalisation in the Context of Industrial Development in Less Developed Countries. Manchester Discussion Papers in Development Studies, no. 8602. University of Manchester.

Craig, J. (2000). Evaluating Privatisation in Zambia: A Tale of Two Processes. Review of African Political Economy, 27(85), 357-366. https://doi.org/10.1080/03056240008704472

Dijkstra, A. G. (2002). The Effectiveness of Policy Conditionality: Eight Country Experiences. Development and Change, 33(2), 307-335. https://doi.org/10.1111/1467-7660.00256

Ensign, M. M. (2001). Conditionality and Foreign Assistance. Journal of International Affairs, 42(1), 147-163.

Felix, D. (1998). IMF Bailouts and Global Financial Flows. Foreign Policy in Focus, 3(5), $1-4$.

Flemming, J., \& Mayer, C. (1997). The Assessment: Public-Sector Investment. Oxford 
Review of Economic Policy, 13(4), 1-11. https://doi.org/10.1093/oxrep/13.4.1

Goodman, J. B., \& Loveman, G. W. (1991). Does Privatization Serve the Public Interest? Harvard Business Review, 69(6), 26-38.

Gupta, S., Schiller, C., \& Ma, H. (1999). Privatization, Social Impact, and Social Safety Nets. IMF Working Paper 99/68, Washington DC. https://doi.org/10.5089/9781451848977.001

IEO. (2002). Evaluation of Prolonged Use of IMF Resources. Independent Evaluation Office. Washington DC: International Monetary Fund.

Islam, M. R. (2015). Privatising government owned enterprises. The Daily Star. [Online] Available: https://www.thedailystar.net/supplements/24th-anniversary-the-daily-star-part-1/pr ivatising-government-owned-enterprises-73282

International Monetary Fund. (2011). Bangladesh: Staff Report for the 2011 Article IV Consultation. Washington DC: International Monetary Fund. https://doi.org/10.5089/9781463923907.002

Karatas, C. (1995). Has Privatisation Improved Profitability and Performance of the SOEs in Turkey? In P. Cook, \& C. Kirkpatrick (Eds.), Privatisation Policy and Performance: International Perspectives (pp. 244-262). New York: Harvester Wheatsheaf.

Khan, A. (2000). Economic development: from independence to the end of the millennium. In R. Jahan (Ed.), Bangladesh: Promise and Performance. New York: Zed Books.

Khatun, F. (2018). Can Bangladesh do without Foreign Aid? Bangladesh: Centre for Policy Dialogue.

Lastra, R. M. (2002). IMF conditionality. Journal of International Banking Regulation, 4(2), 167-182. https://doi.org/10.1057/palgrave.jbr.2340138

Letza, S., \& Smallman, C. (2001). Est in aqua dulci non invidiosa voluptas: In pure water there is a pleasure begrudged by none: on ownership, accountability and control in a privatized utility. Critical Perspectives on Accounting, 12(1), 65-85. https://doi.org/10.1006/cpac.2000.0413

Loc, T. D., Lanjouw, G. E. R., \& Lensink, R. (2006). The Impact of Privatization on Firm Performance in a Transition Economy: The case of Vietnam. Economics of Transition, 14(2), 349-389. https://doi.org/10.1111/j.1468-0351.2006.00251.x

Malmqvist, H. (2000). Development Aid, Humanitarian Assistance and Emergency Relief. Sweden: Ministry of Foreign Affairs.

McMurray, A. J., Pace, R. W., \& Scott, D. (2004). Research: a commonsense approach. Southbank Victoria: Thomson.

Ministry of Finance. (2003). Bangladesh Economic Review 2003. Finance Division, Ministry of Finance, Government of Bangladesh.

Ministry of Finance. (2012). Bangladesh Economic Review 2012. Finance Division, Ministry 
of Finance, Government of Bangladesh.

Momen, M. N. (2007). Implementation of Privatization Policy: Lessons from Bangladesh. The Innovation Journal: The Public Sector Innovation Journal, 12(2).

Morrissey, O. (2004). Conditionality and Aid Effectiveness Re-evaluated. The World Economy, 27(2), 153-171. https://doi.org/10.1111/j.1467-9701.2004.00594.x

Noor, K. B. M. (2008). Case Study: A Strategic Research Methodology. American Journal of Applied Sciences, 11(5), 1602-1604. https://doi.org/10.3844/ajassp.2008.1602.1604

Parry, K. W. (1998). Grounded theory and social process: A new direction for leadership $\begin{array}{llll}\text { research. } & \text { Leadership } & \text { Quarterly, } & \text { 85-105. }\end{array}$ https://doi.org/10.1016/S1048-9843(98)90043-1

Potts, D. (1995). Nationalisation and Denationalisation of State Agriculture in Tanzania 1967-1990. In P. Cook, \& C. Kirkpatrick (Eds.), Privatisation Policy and Performance: International Perspectives. New York: Harvester Wheatsheaf, 178-197.

Privatisation Commission. (2010a). Privatization in Bangladesh Opportunities and Potentials. Privatization Commission, Bangladesh.

Privatisation Commission. (2010b). Study Report of Privatized SOEs. Privatization Commission, Bangladesh.

Privatisation Commission. (2015). Achievement in the Privatization. Privatization Commission, Bangladesh.

Rapley, T. (2007). Doing conversation, discourse and document analysis. California: Sage Publications. https://doi.org/10.4135/9781849208901

Rist, G. (2002). The History of Development: From Western Origins to Global Faith. New Exp. Edition, USA: Zed Books.

Sen, B. (1997). Whither Privatisation: Results of an Exploratory Survey of Disinvested Industries in Bangladesh. Mimeo. Dhaka: BIDS.

Silverman, D. (2005). Doing Qualitative Research. California: Sage Publications.

Sobhan, R. (2002). Privatisation in Bangladesh: An Agenda in Search of a Policy. Bangladesh: Centre for Policy Dialogue.

Stern, N., Dethier, J. J., \& Rogers, H. (2005). Growth and Empowerment. Making Development Happen. Cambridge: The MIT Press. https://doi.org/10.7551/mitpress/3377.001.0001

Stiglitz, J. E. (2003). Globalization and Its Discontents. New York: WW Norton \& Company.

Uddin, S., \& Hopper, T. (2001). A Bangladeshi Soap Opera: Privatisation, Accounting, and Regimes of Control in a Less Developed Country. Accounting Organizations and Society, Oxford, 26(7/8), 643-672. https://doi.org/10.1016/S0361-3682(01)00019-8 


\section{Macrothink}

International Journal of Human Resource Studies

ISSN 2162-3058 2021, Vol. 11, No. 2

World Bank. (1995). Bangladesh: Privatization and Adjustment. Washington DC: World Bank.

World Bank. (2001). Bangladesh Country Assistance Strategy 2001. Washington DC: World Bank.

World Bank. (2006). Bangladesh Country Assistance Strategy 2006. Washington DC: World Bank.

World Bank. (2011a). Bangladesh Country Assistance Strategy 2011. Washington DC: World Bank.

World Bank. (2011b). Bangladesh - Enterprise Growth and Bank Modernization Project. Washington DC: World Bank.

World Bank. (2012). World Bank data sets. Washington DC: World Bank.

Yin, R. K. (2003). Case Study Research: Design and Methods. California: Sage Publications.

\section{Copyright Disclaimer}

Copyright for this article is retained by the author(s), with first publication rights granted to the journal.

This is an open-access article distributed under the terms and conditions of the Creative Commons Attribution license (http://creativecommons.org/licenses/by/4.0/). 